\title{
IN VITRO SYNTHESIS \\ OF BARLEY ENDOSPERM PROTEINS ON WILD TYPE AND MUTANT TEMPLATES
}

\author{
by \\ ANDERS BRANDT \\ Agricultural Research Department - Research Establishment Ris $\emptyset$ \\ DK-4000 Roskilde \\ and \\ JOHN INGVERSEN \\ Department of Physiology, Carlsberg Laboratory \\ Gamle Carlsberg Vej 10 - DK-2500 Copenhagen, Valby
}

Key words: High lysine mutant, low lysine mutant, polyribosomes, hordeins, prolamin

\begin{abstract}
Membrane bound and free polyribosomes were isolated from 20 day old barley endosperms. Sucrose gradient analysis revealed distinct polysomal peaks up to heptamers. The isolated polysomes were active in a cell-free protein synthesizing system employing wheat germ extract. SDS-polyacrylamide gel electrophoresis showed that proteins with molecular weights ranging from 200,000 to 10,000 daltons were synthesized. A substantial part of the polypeptides coded for by the template associated with the membrane bound polysomes was identified as hordeins by their solubility in 55\% isopropanol and by their co-migration with native hordein on SDS-polyacrylamide gels. Membrane bound endosperm polysomes from a barley mutant defective in hordein synthesis produced in the cell-free protein synthesizing system only a small amount of hordein. Conversely membrane bound polysomes from the endosperm of a mutant giving rise to an increased content of some hordein polypeptides catalyzed a preferential synthesis of these polypeptides in vitro. SDS-polyacrylamide gel electrophoresis revealed that the in vitro template activities of the free polyribosomes from the wild type and mutant endosperms were very similar. The resulting polypeptides had not the solubility characteristics of hordeins.
\end{abstract}




\section{INTRODUCTION}

In the developing barley endosperm an intense synthesis of carbohydrates and storage proteins takes place during the grain filling period. Hordeins, the main endosperm storage protein of barley, comprise nearly $50 \%$ of the total proteins in the mature endosperm. The very hydrophobic hordeins are defined by their solubility in 55\% isopropanol $(10,20)$ and are composed of a limited number of polypeptides as analysed by SDS-polyacrylamide gel electrophoresis $(2,12)$. The individual hordein polypeptides are synthesized at even rates during the period of intensive storage protein synthesis (2). $\mathrm{K} \emptyset \mathrm{IE}$ et al. (12) showed that the relative proportions of the high and intermediate molecular weight components of the hordeins change in response to different levels of nitrogen fertilization applied to the growing barley plant. According to OrAM et al. (19) a polymorphism of the electrophoretic mobility of components with intermediate molecular weights is determined by two alleles of a single gene.

The hordeins are deposited in vacuoles of the endosperm cell as protein bodies $(9,18)$. Ultrastructural studies of the developing endosperm reveal an extensive development of the rough endoplasmatic reticulum during the period of storage protein synthesis and protein body formation (18). The morphological pictures suggest that the storage proteins are synthesized on rough endoplasmatic reticulum and transported to the vacuoles for deposition as protein bodies (D. von WETTSTEIN, pers. commun.).

Several single gene mutations affecting the barley endosperm storage proteins are known (8). One such mutant, Risø no. 1508 has a very low content of hordeins in its protein bodies $(2,9,11)$. Another mutant, Ris $ø$ no. 10 is characterised by an increased content of some of the hordein polypeptides (12). The changes in the endosperm storage protein deposition of mutant no. 1508 are due to a single recessive gene (6), which only acts in the endosperm tissue. These endosperm mutants provide a helpful tool to analyse the mechanism of synthesis, transport and deposition of reserve proteins in barley.
Cell free synthesis of plant seed storage proteins has been demonstrated with polyribosomes isolated from the developing seeds of Phaseolus vulgaris $(23)$ and maize $(4,16)$. LARKINS et al. (16) isolated polyribosomes from wild type and high lysine opaque-2 (17) maize endosperm, and obtained cell free synthesis of the alcohol soluble storage protein, zein, with membrane bound polysomes. Whereas polysomes from the wild type sustained synthesis of both zein components, those from opaque- 2 catalyzed only the single zein species, which is characteristic for opaque-2. BURR and BURR (4) studied polyribosomes isolated from a protein body fraction of maize and found these to be active in zein synthesis. They suggested that zein is synthesized directly on the protein body membrane and deposited after transfer across the membrane.

In order to determine, if the membrane bound or free polyribosomes are involved in the synthesis of the barley storage proteins we have established a cell free protein synthesizing system using polysomes from developing barley endosperms and an extract af wheat germ. Membrane bound and free polyribosomes from Bomi barley and its mutants Ris $\varnothing$ no. 1508 and 10 were used as a source for mRNA to direct protein synthesis in this system. The products have been characterized by solubility tests and co-electrophoresis with standards.

\section{MATERIALS AND METHODS}

\subsection{Chemicals}

HEPES (N-2-hydroxyethylpiperazine-N'-2-ethane sulfonic acid), ATP (disodium salt), GTP (sodium salt), phosphoenolpyruvate (tricyclohexylamine salt), puryvate kinase (E. C. no. 2.7.1.40), cycloheximide, chloramphenicol, and puromycin were purchased from Sigma Chemicals. L- $\left(4.5-{ }^{3} \mathrm{H}\right)$-leucine (specific activity 55 $\mathrm{ci} / \mathrm{m}$ mole) were obtained from Radiochemical Center, Amersham, U. K.

\subsection{Plant material}

Barley plants (Hordeum vulgare) cv. Bomi and its mutants Risø no. 10 and 1508 were grown in

Abbreviations used: SDS, sodium dodecyl sulfate; TCA, trichloroacetic acid. 
pots in a growth-chamber under a diurnal cycle of $16 \mathrm{hrs}$ light, $18^{\circ} \mathrm{C}, 60 \%$ relative humidity and $8 \mathrm{hrs}$ dark, $12^{\circ} \mathrm{C}, 80 \%$ relative humidity. Spikes were marked at flowering and harvested 20 days later.

Fresh commercial wheat-germ was obtained from Ringsted Dampmølle, Denmark, and stored in polyethylene bags at $-18^{\circ} \mathrm{C}$.

\subsection{Polysome isolation}

Free and initially membrane bound polysomes were isolated by a procedure slightly modified from LARKINS and Davies (15). All operations were carried out at $2-4^{\circ} \mathrm{C}$. Endosperms (80-100) isolated from freshly harvested spikes as described before (2) were ground in a precooled mortar containing $10 \mathrm{ml} 20 \mathrm{mM}$ HEPES, $\mathrm{pH} 7.6$, $0.2 \mathrm{M}$ sucrose, $55 \mathrm{mM} \mathrm{KCl}, 50 \mathrm{mM} \mathrm{MgCl}_{2}$ and $5 \mathrm{mM} \beta$-mercaptoethanol for $5 \mathrm{~min}$. After the initial grinding further homogenization was done by three strokes in a Potter-Elvehjem homogenizer at 500 r.p.m. The homogenates were centrifuged at $500 \mathrm{x}$ g for $5 \mathrm{~min}$, in a Sorvall SS-34 rotor to remove most of the starch, cell walls and unbroken cells. The supernatant was then centrifuged at $37,000 \times \mathrm{g}$ for $10 \mathrm{~min}$ to separate the free and membrane bound polysomes.

The 37,000 $\mathrm{x}$ g supernatant containing the free polysomes was layered over $4 \mathrm{ml} 1.8 \mathrm{M}$ sucrose in $20 \mathrm{mM}$ HePES, $\mathrm{pH} 7.6,20 \mathrm{mM} \mathrm{KCl}, 10 \mathrm{mM}$ $\mathrm{MgCl}_{2}$ and centrifuged at $160,000 \times \mathrm{g}$ in a Spinco 50 rotor to pellet the polysomes. The $37,000 \times$ g pellet was resuspended in the homogenization buffer containing $1 \%$ Triton X-100 to solubilize the initially membrane bound polysomes and these were then pelleted likewise at $160000 \mathrm{~g}$.

The surface of the polysomal pellets was washed gently in ice-cold distilled water and the pellets resuspended in $20 \mathrm{mM}$ HEPES, $\mathrm{pH} 7.6,55$ $\mathrm{mM} \mathrm{KCl}, 5 \mathrm{mM} \mathrm{MgCl}$ and $2 \mathrm{mM}$ dithiothreitol.

\subsection{Density gradient analysis of polysomes}

Five $A_{260}$ units of polysomes were loaded on the top of an exponential 0.3-1.0 M sucrose gradient in polysome suspension buffer. The loaded gradients were centrifuged at $154,000 \mathrm{~g}$ for 1 hour and 3 hours in a Spinco SW 40 rotor. The gradients were tapped from the top and the transmission at $254 \mathrm{~nm}$ was monitored continuously.

\subsection{Electron microscopy of polysomes}

The polysomal pellets were fixed in $20 \mathrm{mM}$ HEPES, $\mathrm{pH} 7.6,50 \mathrm{mM} \mathrm{KCl}, 5 \mathrm{mM} \mathrm{MgCl}{ }_{2}$ containing $2 \%$ glutaraldehyde for 1 hour at $0^{\circ} \mathrm{C}$. After washing with buffer 3 times the pellet was postfixed with $2 \% \mathrm{OsO}_{4}$ in $20 \mathrm{mM}$ HEPES, $\mathrm{pH}$ 7.6, $50 \mathrm{mM} \mathrm{KCl}, 5 \mathrm{mM} \mathrm{MgCl}$ for 1 hour. The fixed pellet was then washed in water and stained with $0.5 \%$ uranyl acetate for 2 hours at $20^{\circ} \mathrm{C}$. After dehydration in a graded series of ethanol the material was embedded in a low viscosity epoxy resin according to SPURR (22). Sections were cut on a Reichert Ultramicrotome and analysed in a Siemens Elmiskop 102 after contrasting with uranyl acetate and lead citrate.

\subsection{Cell-free protein synthesizing system}

A preincubated wheat-germ S-30 extract was prepared as described by ROBERTS and Patterson (21).

The standard reaction mixture for incorporation of amino acids into proteins contained 20 $\mu l$ of the preincubated wheat-germ S-30 fraction, 1-2 $\mathrm{A}_{260}$ units of polysomes, $1 \mathrm{mM} \mathrm{ATP,} 20$ $\mu \mathrm{M}$ GTP, $8 \mathrm{mM}$ phosphoenolpyruvate, $40 \mu \mathrm{g} / \mathrm{ml}$ phosphoenolpyruvate kinase, $2 \mathrm{mM}$ dithiothreitol, $3.5 \mathrm{mM} \mathrm{Mg}$-acetate, $60 \mathrm{mM} \mathrm{KCl}, 5 \mu \mathrm{ci}$ ${ }^{3} \mathrm{H}$-leucine, $0.08 \mathrm{mM}$ of each of the unlabeled 19 other amino acids in a total volume of $60 \mu$ l. Supplementation with tRNA was not used.

The reaction mixture was incubated at $26^{\circ} \mathrm{C}$ for $30 \mathrm{~min}$. After the incubation $50 \mu \mathrm{l}$ of the reaction mixture were pipetted onto Whatmann no. $3 \mathrm{~mm}$ filter paper discs. The filters were washed in $10 \%$ trichloracetic acid (TCA) (w/v), $2 \mathrm{mM}$ leucine for $10 \mathrm{~min}$, in $5 \% \mathrm{TCA}$ at $90^{\circ} \mathrm{C}$ for 10 $\mathrm{min}$ and in 5\% TCA at room temperature, whereafter they were dried by successive dipping into ethanol (96\%); ethanol: diethylether (3:1) and diethylether. The radioactivity precipitated on the discs was counted in a toluene based scintillator containing $0.4 \%$ PPO (diphenyloxazole) and $0.01 \%$ POPOP (2,2'-p-phenylen-bis (5-phenyloxazole)) in a Nuclear Chicago Mark III liquid scintillation spectrometer. 


\subsection{SDS-polyacrylamide gel electrophoresis of polypeptides synthesized in the cell free system}

After $40 \mathrm{~min}$ incubation the reaction mixture (scaled up 5 times) was divided into two equal parts and the reaction was stopped by adding $20 \%$ TCA, with $4 \mathrm{mM}{ }^{3} \mathrm{H}$-leucine to give a final concentration of $10 \%$ TCA, $2 \mathrm{mM}$ leucine. After $\mathrm{I} \mathrm{hr}$ on ice the precipitated proteins were centrifuged at $8000 \mathrm{rpm}$ in a Sorvall SS-34 rotor and the sediment was dried by washing with 1 $\mathrm{ml}$ ethanol, $1 \mathrm{ml}$ ethanol:diethylether (3:1), and $1 \mathrm{ml}$ diethylether. For analysis of total polypeptides the dried precipitate was dissolved in 100 $\mu \mathrm{l} 0.1 \mathrm{M} \mathrm{TRIS} / \mathrm{HCl} \mathrm{pH} 8.5,1 \%$ SDS and $2 \%$ $\beta$-mercaptoethanol and heated at $70^{\circ} \mathrm{C}$ for $1 \mathrm{hr}$. The polypeptides soluble in $55 \%$ isopropanol were extracted from the dried TCA precipitate twice with $0.5 \mathrm{ml} 55 \%$ isopropanol at $20^{\circ} \mathrm{C}$ for $30 \mathrm{~min}$ after $250 \mu \mathrm{g}$ native hordein in $55 \%$ isopropanol was added during the extraction as carrier. The extracts were evaporated to dryness at room temperature and redissolved for electrophoresis in the same buffer as for total polypeptides.

Electrophoresis was performed in $7.5 \%$ polyacrylamide gels containing $0.1 \%$ SDS in $0.125 \mathrm{M}$ $\mathrm{TRIS} / \mathrm{HCl}, \mathrm{pH} 8.9$ and with an electrode buffer containing $0.1 \% \mathrm{SDS}$ in $0.025 \mathrm{M}$ TRIS/glycine, $\mathrm{pH}$ 8.4. The gels were pre-electrophoresed at 2.5 $\mathrm{m}$ amp/gel for $1 \mathrm{hr}$. Then aliquots of the samples were mixed with sucrose and bromphenol blue and layered on top of the gels. Electrophoresis was caried out at $2.5 \mathrm{~m}$ amp/gel towards the anode until the marker dye reached the bottom of the gels. Native hordein, dissolved at the in vitro products, was electrophoresed in a separate tube as a standard.

The native hordein standard was stained with Coomassie brilliant blue R 250 and scanned at $620 \mathrm{~nm}$ as described earlier (2). The gels containing the in vitro synthesized polypeptides were fixed in $10 \%$ TCA over night and cut into $2 \mathrm{~mm}$ slices and the gel hydrolyzed with $200 \mu \mathrm{l}$ $30 \% \mathrm{H}_{2} \mathrm{O}_{2}$ at $75^{\circ} \mathrm{C}$ for $2 \mathrm{hrs}$. After cooling to room temperature the samples were mixed with $10 \mathrm{ml}$ of toluene: TRITON X-100 (3:1), containing $0.2 \%$ POP, $0.1 \%$ POPOP and kept in the dark at $4^{\circ} \mathrm{C}$ for $48 \mathrm{hrs}$ to reduce chemoluminescence before counting.

\section{RESULTS}

\subsection{Isolation and characterization of barley endo- sperm polyribosomes}

The resuspended polyribosomal pellets from several independent isolations had an average $\mathrm{A}_{260} / \mathrm{A}_{280}$ ratio of 1.82 indicating pure preparations of polyribosomes. Per endosperm $0.40 \pm$ $0.06 \mathrm{~A}_{260}$ units were obtained at 8 different occasions. The amount isolated was independent of the genotype of the endosperms. Consistently a ratio of 0.6 was found for free to membrane bound polyribosomes indicating that at this stage of endosperm development the wild type and the mutant endosperm are equal in this respect.

Analysis of the isolated polyribosomes by density gradient centrifugation (Fig. 1) revealed a monosome peak and discrete peaks up to heptamers. Polyribosomes of higher order are present in the unresolved region towards or at the bottom of the gradient.

Electron microscopy of sections through the polyribosomal pellets gave the impression of uncontaminated preparations (Fig. 2). From individual micrographs of sections the length distribution of polyribosomes cannot be determined but coherent stretches of up to 15 ribosomes were detectable.

\subsection{Cell-free synthesis of barley endosperm pro- teins}

The isolated polyribosomes from the barley endosperm were active in a cell free protein synthesizing system with wheat germ extract. The incorporation of ${ }^{3} \mathrm{H}$-leucine into proteins increased linearly as a function of added polyribosomes up to $2 \mathrm{~A}_{260}$ units, and as a function of time for 30 minutes. The incorporation was dependent on magnesium content with a sharp optimum at a concentration of $3.5 \mathrm{mM}$. The system was highly dependent on ATP as well as an energy generating system and was susceptible to ribonuclease (Table 1). Puromycin, which under certain conditions functions as a specific inhibitor of polypeptide chain elongation inhibited incorporation by $50 \%$ at the concentration used. This might indicate that initiation of new polypeptide chains can take place. The slight inhibition caused by chloramphenicol provides evidence that the protein was synthesi- 


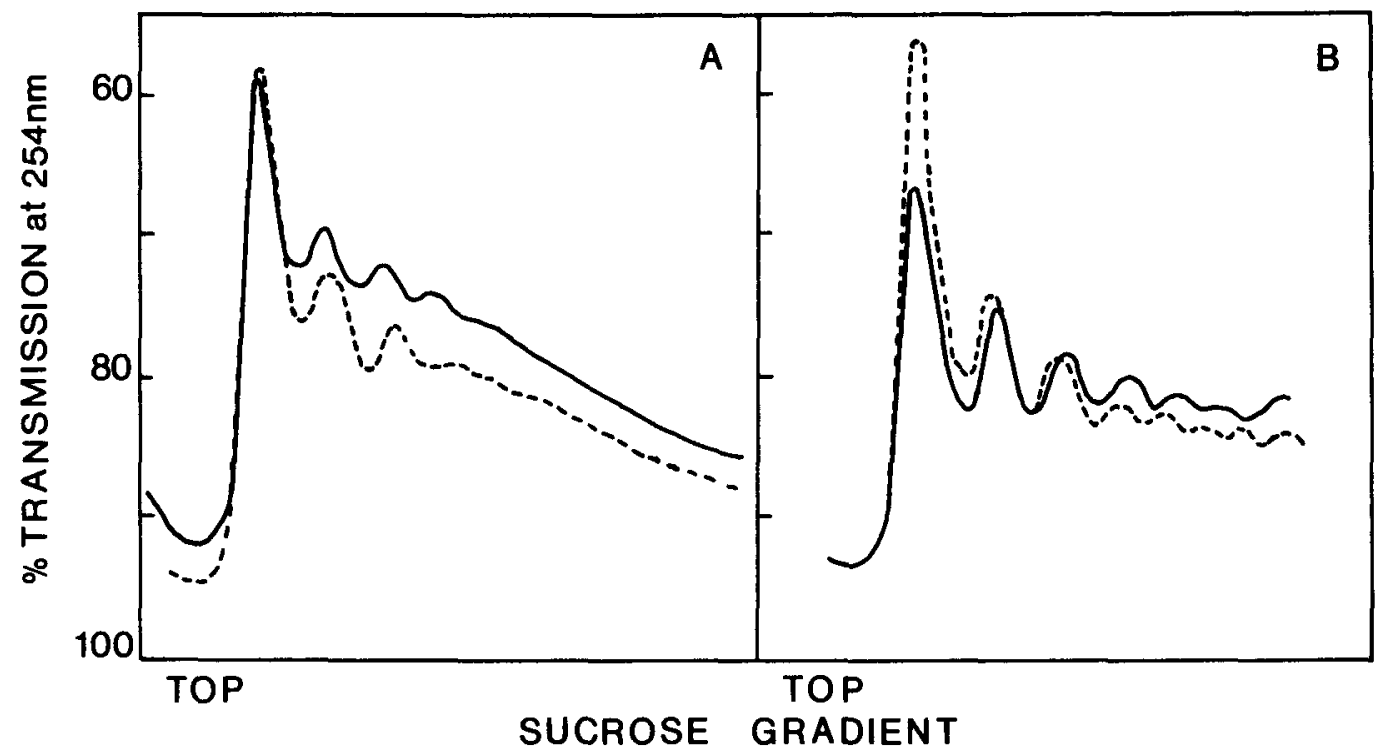

Figure 1. Sucrose density profile of barley endosperm polyribosomes from Bomi barley and its mutant 1508.

Polyribosomes were isolated from the 20 day old Bomi barley endosperm by homogenising the tissue in $20 \mathrm{mM}$ HEPES pH 7.6 containing $0.2 \mathrm{M}$ sucrose, $55 \mathrm{mM} \mathrm{KCl,} 5 \mathrm{mM} \mathrm{MgCl}, 5 \mathrm{mM}$ mercaptoethanol and $1 \%$ Triton $\mathrm{X}-100$. The homogenate was centrifuged at $10,000 \mathrm{~g}$ for $10 \mathrm{~min}$ in a Sorwall SS-34 rotor. The supernatant was layered over $20 \mathrm{mM}$ HEPES pH 7.6 containing $1.8 \mathrm{M}$ Sucrose and $10 \mathrm{mM} \mathrm{MgCl}$ and centrifuged at $160,000 \mathrm{~g}$ for 2 hrs in a Spinco 50 rotor. The resuspended polyribosomal pellet had an $A_{260} / A_{280}$ ratio of 1.89 , and are considered as a total polyribosomal preparation from the barley endosperm. Five $A_{260}$ units were loaded on a 0.3-1.0 M exponential sucrose gradient. The gradient was centrifuged at $154.000 \mathrm{~g}$ for $1 \mathrm{hr}(\mathrm{A})$ and $3 \mathrm{hrs}(\mathrm{B})$ in a Spinco SW-40 rotor at $2^{\circ} \mathrm{C}$. The gradient was tapped from the top and the polysome profile monitored by continuous measurement of per cent transmission at $254 \mathrm{~nm}$. Full line: Bomi; broken line: mutant no. 1508.

\section{Table I}

Characterization of the cell free protein synthesizing system directed by 20 day old Bomi barley endosperm polyribosomes.

The standard reaction mixture described under Materials and Methods was used. Isolation of polyribosomes is described under Figure 1.

\begin{tabular}{l|r|r}
\hline & $c p m / A_{260}$ unit & $\%$ of control \\
\hline Complete & 87,489 & 100 \\
- S-30 wheat-germ & 8,778 & 10 \\
- Polyribosomes & 1,733 & 2 \\
- ATP & 35,244 & 40 \\
- ATP, GTP, phosphoe- & & \\
nolpyruvate, phospho- & & \\
kinase & 4,156 & 5 \\
+ 30 $\mu$ g/ml RNase & 4,467 & 5 \\
+ 0.06 mM puromycin & 47,489 & 54 \\
+ 0.06 mM chloramphe- & & \\
nicol & 77,955 & 83 \\
+ I mM cycloheximnide & 4,270 & 5 \\
\hline
\end{tabular}

zed on $80 \mathrm{~S}$ cytoplasmic ribosomes (Table I) This is corroborated by the total inhibition effected by cycloheximide, a specific inhibitor of translation on cytoplasmic ribosomes. The incorporation rates of ${ }^{3} \mathrm{H}$-leucine into proteins averaged $0.02 \mathrm{p} \mathrm{mole} / \mathrm{A}_{260} \mathrm{unit} / \mathrm{min}$.

The activities of TCA precipitable material per unit polysomes synthesized by the free and membrane bound polyribosomes from the endosperm of Bomi barley, mutant no. 10 and 1508 are presented in Table II. Very similar activities were observed with the initially membrane bound polyribosomes from the endosperm of the different genotypes. The activities achieved by the free polyribosomes from Bomi barley and its mutant no. 1508 were the same but lower than the activities measured for the membrane bound polyribosomes, while the activity in the preparation containing the free polyribosomes from mutant no. 10 was significantly higher. The activities obtained with the free polyri- 




Figure 2. Barley endosperm polyribosomes of mutant no. 1508.

A polyribosomal pellet prepared as described under Fig. 1 was fixed, stained and sectioned for electron microscopy. Magnification x 82000 .

bosomes in different preparations was variable possibly due to minor differences in the developmental stage of the endosperms.

The fraction of the synthesized product soluble in $55 \%$ isopropanol depended on the source of the polyribosomes. The extraction procedure used in these experiments solubilized between 6 and $34 \%$ of the total product. The in vitro product synthesized with the free polysomes from Bomi barley and mutant no 10 endosperms was less soluble in $55 \%$ isopropanol than that from mutant no. 1508 (Table II). The reverse pattern was observed when initially membrane bound polyribosomes were used as template. Membrane bound polyribosomes from Bomi barley and mutant no. 10 code for a relatively high proportion of proteins soluble in 55\% isopropanol while those of mutant no. 1508 code for significantly smaller amounts.

The total TCA precipitable proteins as well as the protein soluble in $55 \%$ isopropanol were analysed by SDS-polyacrylamide gel electrop-

\section{$\underline{\text { Table II }}$}

Efficiency of the cell free protein synthesizing system employing free and initially membrane bound polyribosomes isolated from 20 days old barley endosperm and S-30 wheat germ extract.

The proportion of the in vitro synthesized barley endosperm proteins, which are soluble in $55 \%$ isopropanol (= hordeins) is also given. The endosperm of Bomi barley contains $40 \%$, mutant no. $15089 \%$, and mutant no. 10 more than $50 \%$ of the total endosperm proteins as hordeins at maturity.

\begin{tabular}{l|r|c}
\hline $\begin{array}{l}\text { Origin of } \\
\text { polyribosomes }\end{array}$ & $\mathrm{cpm} / \mathrm{A}_{260}$ unit & $\begin{array}{c}\text { per cent } \\
\text { cpm soluble } \\
\text { in isopro- } \\
\text { panol }\end{array}$ \\
\hline $\begin{array}{l}\text { Free polyribosomes } \\
\text { Bomi }\end{array}$ & 54,300 & 9.9 \\
M 1508 & 54,000 & 24.2 \\
M 10 & 185,000 & 6.1 \\
\hline Initially membrane- & & \\
bound & 116,300 & 17.8 \\
Bomi & 120,600 & 9.5 \\
M 1508 & 118,000 & 33.9 \\
M 10 & \\
\hline
\end{tabular}




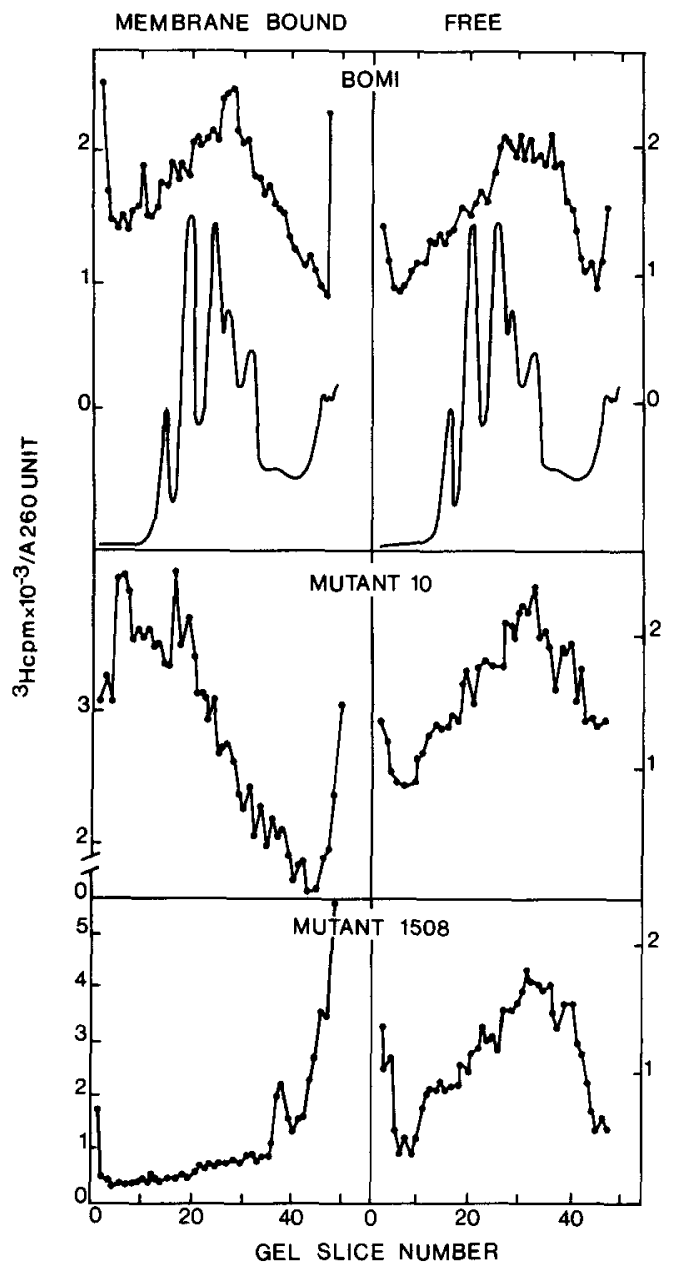

Figure 3. Polyacrylamide gel electrophoresis of the total polypeptides synthesized in vitro.

The in vitro assays were performed with membrane bound and free polyribosomes from 20 day old endosperms of Bomi barley and its mutants no. 10 and 1508. For details regarding protein preparations and electrophoresis see Materials and Methods. The graphs show plots of ${ }^{3} \mathrm{H} \mathrm{cpm} / \mathrm{A}_{260}$ unit of polyribosomes of individual slices versus migration distance (dotted line), and a densitometric tracing of a native hordein standard (full line). Direction of electrophoresis was from left to right.

horesis. The radioactivity was determined in $2 \mathrm{~mm}$ slices and plotted as $\mathrm{cpm} / \mathrm{A}_{260}$ unit versus migration distances (Fig. 3 and 4). The free polyribosomes from the barley endosperm code for polypeptides covering the entire molecular range of the gel between 200,000 and 10,000 dalltons (Fig. 3). Polypeptides with molecular weights below 40,000 daltons were the most

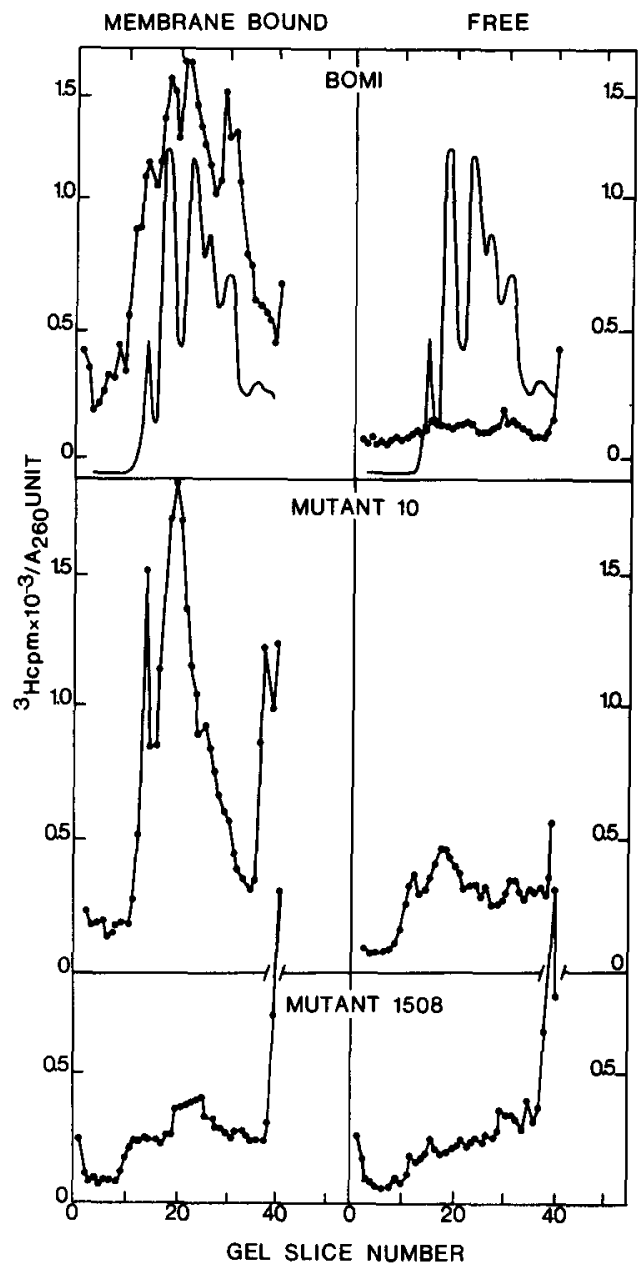

Figure 4. Polyacrylamide gel electrophoresis of the in vitro synthesized polypeptides which were soluble in $55 \%$ isopropanol.

The in vitro assays were performed with membrane bound and free polyribosomes from 20 days old endosperms from Bomi barley and its mutants no. 10 and 1508 . For details regarding protein preparations and electrophoresis see Material and Methods. The graphs show plots of ${ }^{3} \mathrm{H} \mathrm{cpm} / \mathrm{A}_{260}$ unit of polyribosomes of individual slices versus migration distance (dotted line) and a densitometric tracing of a native hordein standard (full line). Direction of electrophoresis was from left to right.

prominent. The polypeptides synthesized with the free polyribosomes from mutant no. 10 and 1508 endosperm as templates in the cell free system could not be distinguished from the polypeptide pattern obtained with those from Bomi barley. It is evident from Fig. 4 that the free polyribosomes did not code for substantial 
amounts of polypeptides which co-migrated with native hordeins. The free polysomes from the mutant no. 1508 endosperm however coded for considerable larger amounts of unidentified isopropanol soluble low molecular weight polypeptides than the free polyribosomes from Bomi barley and mutant no. 10 endosperm (Fig. 4).

The templates of the membrane bound polyribosomes isolated from the Bomi barley endosperm were translated into many polypeptides with different molecular weights. However, the polypeptides coded for by the membrane bound polyribosomes from mutant no. 10 and 1508 differed in molecular weight distribution (Fig. 3). The polyribosomes from mutant no. 10 produced mainly high molecular weight polypeptides whereas the polyribosomes from mutant no. 1508 resulted primarely in polypeptides with low molecular weights. The polypeptides soluble in 55\% isopropanol and made on the membrane polyribosomes from Bomi barley and mutant no. 10 endosperm co-migrated with the native hordeins (Fig. 4). The polyribosomes from mutant no. 10 have, compared with Bomi polyribosomes, an increased activity for synthesis of high molecular weight hordeins. Finally, membrane bound polyribosomes from mutant no. 1508 are very defective in directing the synthesis of the predominant hordein polypeptides but direct the synthesis of low molecular weight polypeptides.

As control the products synthesized without added barley polyribosomes were analysed by electrophoresis. Distinct peaks were absent and the radioactivity per gel slice did not exceed $300 \mathrm{cpm}$.

\section{DISCUSSION}

\subsection{Isolation of polyribosomes}

The procedure used for the isolation of polyribosomes at a high magnesium concentration yields pure preparations as judged from the $A_{260} / A_{280}$ ratios and electron microscopy (Fig. 2). Large size polyribosomes were present in the preparations when analysed by sucrose gradient centrifugation and the polyribosomes were active in directing cell-free protein synthesis. From these data we conclude, in agree- ment with what has been reported for barley leaves and maize endosperms $(3,16)$, that 50 $\mathrm{mM}$ magnesium and $50-60 \mathrm{mM}$ potassium are sufficient to stabilize the polyribosomes during the extraction from the barley endosperm. The mutant no. 1508 endosperm contained at least twice the amount of ribonuclease found in the Bomi endosperm. It is not likely that the elevated RNase level of the mutant no. 1508 endosperm caused increased polysomal breakdown since the sucrose density gradient profiles of the polyribosomes isolated from mutant no. 1508 closely resembles the profile of the polyribosomes isolated from the Bomi barley endosperm (Fig. 1). Neither did the electron micrograph reveal differences between the polysomal preparations of the three genotypes. We conclude therefore that the polysomal breakdown during isolation was not influenced by the source of the polyribosomes. Several independent isolations of polyribosomes yielded the same amount per endosperm. To what extent the ratio between free and initially membrane bound polyribosomes reflects the situation in the cell is difficult to evaluate, but the differences in template activity displayed in the cellfree protein synthezising system (Fig. 3 and 4), distinguished the isolated polyribosomes as functionally two distinct classes.

\subsection{Cell-free synthesis of barley endosperm proteins}

The present study shows that the main storage protein in the barley endosperm, hordein, is synthesized on membrane bound polyribosomes (Table II and Fig. 4). The low amount of isopropanol soluble polypeptides which could be extracted from the TCA insoluble material synthesized in vitro is probably due to irreversible denaturations of polypeptides by the TCA precipitation procedure. On the other hand it is evident that the isopropanol soluble in vitro products of the Bomi polyribosomes are different from those of the mutants.

Since the yield of isolated membrane bound polyribosomes per endosperm was independent of the genetic constitution, the observed differences in the electrophoretic patterns of the in vitro synthesized products (Fig. 3 and 4) signify different composition of the polysomal messages in 
the endosperm cell. The possiblity that supernatant factors affected the initiation and elongation of the individual polypeptides on the polyribosomes of different origin is ruled out since all translations were performed with wheatgerm supernatant factors.

Thus we conclude, that mutant no. 10 polyribosomes on the rough endoplasmatic reticulum contained more mRNA's for high molecular weight hordeins than those on the reticulum of Bomi endosperm. This is in agrement with the observed hordein composition in vivo (12).

Similarly the rough endoplasmatic reticulum of the mutant no. 1508 endosperm cell is mainly occupied by polyribosomes with mRNA's which code for low molecular weight polypeptides. The electrophoretic pattern of polypeptides synthesized by the mutant no. 1508 in vitro resembles the pattern of the hordeins made in the grain $(2,12)$. In this case the overall hordein content of the mature endosperm is only $20 \%$ of the amount found in the Bomi endosperm (10) and the morphological portions of the protein bodies typical for hordeins are only scarcely represented $(9)$.

The hordein polypeptides have to be transported from the site of synthesis to the site of deposition in the vacuoles of the endosperm cell. An analogy with the synthesis of secretory proteins in animals is here of interest. JAMIESON and PALADE $(13,14)$ demonstrated that the secretory proteins of the pancreatic exocrine cell are synthesized on the rough endoplasmatic reticulum and transported to condensing vacuoles of the Golgi apparatus. The vacuoles are later transformed to zymogen granules by concentration of their contents. An analogous deposition mechanism has been inferred for the storage protein of the dicotyledonous seed (5). Autoradiographic studies on tissue slices from the developing seed of Vicia faba (1) showed that labelled amino acids first concentrated around the rough endoplasmatic reticulum and appeared later in the protein bodies. As suggested by MUNCK and VON WETTSTEIN (18) from ultrastructural studies, the barley hordeins are probably synthesized on the surface of the rough endoplasmatic reticulum moved into its lumen and from there transferred in membrane vesicles to the Golgi apparatus for finally to be deposited in the vacuoles as protein bodies. Further studies are required to determine whether the mutation in the 1508 gene causes the $a b$ sence of significant amount of mRNA or a failure of the mRNA to be translated. Likewise the molecular nature of mutant no. 10 remains to be elucidated.

The free polyribosomes from Bomi barley, mutant no. 10 and mutant no. 1508 most likely coded for endosperm globulin and glutelin since these proteins are synthesized at this endosperm developmental stage (2). Mutant no. 1508 is known to have some compensating synthesis of glutelins in response to the low hordein synthesis at later stages of endosperm development (2). Whether this is reflected in a changed template activity of the free polyribosomes from the mutant no. 1508 endosperm is to be investigated.

\section{ACKNOWLEDGEMENT}

We would like to thank Professor D. VoN WETTSTEIN for valuable discussions and for helpful criticism during the preparation of the manuscript. The technical assistance from BIBI STAMPE ANDERSEN is gratefully acknowledged.

\section{REFERENCES}

1. Bailey, C. J., A. CobB \& D. Boulter: A cotyledon slice system for the electron autoradiographic studies of the synthesis and intracellular transport of seed storage protein of Vicia faba. Planta (Berl) 95: 103-118 (1970)

2. BRANDT, A.: Endosperm protein formation during kernel development of wild type and high lysine barley. Cereal Chemistry (In press)

3. Breen, M. D., E. I. Whitehead \& D. G. KENEFIC: Requirements for extraction of polyribosomes from barley tissue. Plant Physiol. 49: 733-739 (1971)

4. BURR, B. \& F. A. BURR: Zein synthesis in maize endosperm by polyribosomes attached to protein bodies. Proc. Nat. Acad. Sci. (USA) 73: 515-519 (1976)

5. Dieckert, J. M. \& M. C. Dieckert: The deposition of vacuolar protein in ojl-seeds. In: sSymposium on seed proteinsw. G. E. INGLETT ed., Avi Publishing Comp., Westport, Connecticut pp. $52-85(1972)$ 
6. Doll, H.: Inheritance of the high-lysine character of a barley mutant. Hereditas 74: 293-294 (1973)

7. Doll, H.: Genetic studies of high-lysine barley mutants. In: "Barley Genetics III. Horst Gaul ed., Verlag Karl Thiemig, München. pp. 542-546 (1976)

8. Doll, H., B. KøIE \& B. O. EgGum: Induced high lysine mutants in barley. Radiation Botany 14: 73-80(1974)

9. INGVERSEN, J.: Structure and composition of protein bodies from wild type and high lysine barley endosperm. Hereditas 81: 69-76 (1975)

10. INGVERSEN, J. \& B. KøIE: Lysine rich proteins in the saltsoluble protein fraction of barley. Phytochem. 12: 73-78 (1973)

11. IngVersen, J., B. KøIE \& H. Doll: Induced seed protein mutant of barley. Experientia 29: 1151-1152(1973)

12. KøIE, B., J. Ingversen, A. J. ANdersen, H. Doll \& B. O. EgGuM: Composition and nutritional quality of barley protein. In: Evaluation of seed protein alterations by mutation breeding, Int. Atomic Energy Agency, Panel Proc. Ser. Sti/Publ/426. Vienna, pp. 55-61 (1976)

13. Jamieson, J. D. \& G. E. PALAdE: Intracellular transport of secretory proteins in the pancreatic exocrine cell. I. Role of the peripheral elements of the Golgi Complex. J. Cell. Biol. 34: 577-596 (1967)

14. Jamieson, J. D. \& G. E. Palade: Intracellular transport of secretory proteins in the pancreatic exocrine cell. II. Transport to condensing vacuoles and zymogen granules. J. Cell. Biol. 34: 597-615 (1967)
15. Larkins, B. A. \& E. Davies: Polyribosomes from peas. V. An attempt to characterize the total free and membrane bound polysomal population. Plant Physiol. 55: 749-756 (1975)

16. LaRkins, B. A., C. E. Bracker \& C. Y. TsaI: Storage protein synthesis in maize. Isolation of zein synthesizing polyribosomes. Plant Physiol. 57: 740-745 (1976)

17. Mertz, E. T., L. Bates \& O. E. Nelson: Mutant gene that changes protein composition and increases lysine content in maize endosperm. Science 145: 279-280(1964)

18. MUNCK, L. \& D. VON WetTStein: Effects of genes that changes the amino acid composition of barley endosperm. In: Genetic improvement of seed proteins. Proc. of a workshop 18-20 March 1974. National Academy of Sciences, Washington D. C. pp. 71-82 (1976)

19. Oram, R. N., H. DOll \& B. KøIE: Genetics of two storage protein variants in barley. Hereditas 80: 53-58 (1975)

20. Osborne, T. B.: The proteids of barley. J. Am. Chem. Soc. 17: 539-567 (1895)

21. Roberts, B. E. \& B. M. Patterson: Efficient translation of tobacco mosaic virus RNA and rabbit globin 9 S RMA in a cell free system from commercial wheat germ. Proc. Nat. Acad. Sci. (USA) 70: 2330-2334 (1973)

22. SpurR, A. R.: A low viscosity epoxy resin embedding medium for electron microscopy. J. Ultrastructural Res. 26: 31-43 (1969)

23. Sun, S. M., U. Buchbinder \& T. C. Hall: Cell free synthesis of the major storage protein of bean. Phaseolus vulgaris L. Plant Physiol. 56: 780-785 (1975) 